ROCZNIKI HUMANISTYCZNE

Tom LXVII, zeszyt $10-2019$

DOI: http://dx.doi.org/10.18290/rh.2019.67.10-12

\title{
CODZIENNIK ROSYJSKI - NIEZBĘDNIK W PRACY NAUCZYCIELA
}

Każdego roku poznaję osoby w różnym wieku, które chcą pogłębiać swoją znajomość języka rosyjskiego. Są to m.in. uczniowie, dążący do zdania egzaminu maturalnego z języka rosyjskiego na poziomie rozszerzonym, przyszły student reżyserii zafascynowany światem kina rosyjskiego, pisarz, który fabułę swojej powieści umieszcza w realiach Rosji, muzyk, tłumaczący utwory rosyjskie, inżynier i biznesmen, którzy współpracują z rosyjskimi koncernami. Ludzie ci są świadomi, jak ważna jest znajomość tego języka wschodniosłowiańskiego na współczesnym rynku pracy, np.: w firmach, urzędach celnych, sądownictwie, straży granicznej, mediach, branży turystycznej itp.

Codziennik rosyjski to kompendium wiedzy na temat języka i kultury rosyjskiej. Autorki książki: Olga Tatarchyk, Jelena Wysokińska i Volha Liauchuk to lektorki szkoły języka rosyjskiego „Słowianka”. Pozycja wydana przez Wydawnictwo Poltext w Warszawie w 2018 r. przeznaczona jest dla uczących się języka rosyjskiego na poziomach: B1-C1, dla biznesmenów, podróżników oraz osób przygotowujących się do egzaminów i pragnących poszerzyć swoją wiedzę o Rosji.

Codziennik rosyjski składa się z dwóch zasadniczych części: Kalendarza oraz Dodatku. Kalendarz rozpisany na każdy dzień roku zawiera cytaty słynnych ludzi, idiomy, przysłowia, dowcipy, rady dotyczące sposobów opanowania języka oraz różne ciekawostki, dotyczące m.in. rosyjskich przedmiotów codziennego użytku, tradycji ludowych, waluty, kosmonautyki (np. кокошник, Белка и Стрелка, копейка, баня, печка, гжель). Dodatek to własne plany na każdy tydzień, podsumowanie tygodniowej nauki i wnioski do dalszej pracy, które powinny być regularnie formułowane przez uczącego się.

Książka przyciąga uwagę bogactwem interesujących tekstów o świętach, tradycjach i zwyczajach obchodzonych w Rosji oraz atrybutach towarzyszących tym wydarzeniom. Większość tekstów napisana jest w języku rosyjskim: Новый год, 1 сентября- День знаний, Иван Купала, День России, День Победы, Пасха, Масленииа, 8 марта, День защитника отечества, Татьянин день, Рождество, География России. Po polsku zamieszczone są: Święto kina 
rosyjskiego, Hymn Rosji, Łamacz języka Liguria. Dzięki nim uczący się ma możliwość porównania kalendarza juliańskiego z gregoriańskim, poznania świąt religijnych i państwowych obchodzonych w Rosji oraz związanych z nimi tradycji i zwyczajów. Teksty te są dobrym sposobem wzbogacania zasobu leksykalnego, rozwijania sprawności rozumienia tekstu pisanego. Zamieszczone tu opisy różnych świąt, np. Nowego Roku, świąt Bożego Narodzenia czy Międzynarodowego Dnia Kobiet, służą porównaniu realiów rosyjskich z polskimi.

W Codzienniku zawarte są również teksty piosenek i pieśni rosyjskich oraz fragmenty wierszy poetów rosyjskich. Znajdziemy tu następujące utwory: Катюша, Учат в школе, День Победы, В Вифлееме тишина, А. Пугачёва Миллион алых роз, В. Высоцкий Песня о друге, Б. Окуджава Молитва i inne. Teksty te służą poszerzeniu wiedzy na temat kultury i literatury rosyjskiej. Pomagają ćwiczyć i utrwalać prawidłową wymowę i akcent. Pełnią również rolę zabawy oraz inspirują do pogłębienia informacji na temat wymienionych poetów, pisarzy i piosenkarzy.

Autorki zadbały także o przekazanie przydatnych treści językowych. Zainteresowany nauką języka rosyjskiego czytelnik odnajdzie w recenzowanej książce informacje o paronimach, homonimach międzyjęzykowych, najczęściej używanych rzeczownikach i czasownikach rosyjskich, nazwach krajów i narodowości, skrótach w języku rosyjskim, odgłosach zwierząt w Rosji i w Polsce, najpopularniejszych nazwiskach rosyjskich. Powyższe zjawiska językowe są bodźcem do utrwalenia deklinacji i koniugacji w języku rosyjskim, zapoznania się z tzw. fałszywymi przyjaciółmi tłumacza. W celu nawiązania korespondencji z rodzimymi użytkownikami języka autorki prezentują schematy pisania listów i podań. Atutem książki są krzyżówki tematyczne: wiosna, jesień, teatr i kino oraz testy do rozwiązania: o pamiątkach Rosji, znanych miejscach w Moskwie i Sankt Petersburgu. Niewątpliwie stanowią one rodzaj ćwiczeń utrwalających poznaną leksykę, skłaniają do samooceny i samorozwoju.

Zamieszczone w Codzienniku przepisy na potrawy kuchni rosyjskiej obrazują styl życia Rosjan, tradycje kulinarne kraju. Łącznie z ciekawostkami na temat pieca rosyjskiego, chleba, naczyń drewnianych i samowarów stanowią cenne źródło wiedzy na temat kuchni rosyjskiej. Następujące przepisy dań rosyjskich: сочиво, суп окрошка, блинчики, салат Оливье inspirują do ćwiczeń translatorskich, utrwalenia nazw artykułów spożywczych, jednostek i opakowań, a także do samodzielnego przygotowania tych potraw.

Zaletą recenzowanej pozycji są autentyczne fotografie, które ukazują np. najdłuższe schody w Rosji z Niżnego Nowogrodu, wyspę Olchon na jeziorze Bajkał, Muzeum Kosmonautyki w Moskwie, rzeźby z lodu z Ufy, meteoryt z Czelabińska i inne. Na wielu zdjęciach przedstawione są zabytki Moskwy 
i Sankt-Petersburga. Szata graficzna służy ukazaniu bogactwa i różnorodności Rosji pod względem kulturowym, etnicznym, wyznaniowym, architektonicznym, krajobrazowym. Motywuje do rozwijania sprawności mówienia w języku rosyjskim. Wizualizacja informacji kulturowej uatrakcyjnia naukę języka, jest bardziej sugestywna od tej przekazanej przy użyciu wyłącznie kodu werbalnego.

Poprzez odwołania do stron internetowych autorki motywują uczących się do słuchania rosyjskiego radia (www.russiafm.net), zapoznania się ze sztuką rosyjską, np. Galerią Trietiakowską w Moskwie (https://www.tretyakovgallery. ru) czy Ermitażem w Sankt-Petersburgu (http://hermitagemuseum.org/wps/ portal/hermitage). Do zgłębiania tajników kultury Rosji służą także zawarte tu cytaty, przysłowia i anegdoty. Uczący się ma możliwość utrwalania sprawności rozumienia tekstu słuchanego i pisanego, kształcenia czytania i udzielania wypowiedzi ustnych w języku rosyjskim. Przysłowia i cytaty są dobrym sposobem na ćwiczenia fonetyczne (prawidłowy akcent, wymowa spółgłosek i samogłosek rosyjskich). Zamieszczone tu humorystyczne monologi i dialogi umożliwiają kształtowanie sprawności mówienia poprzez np. odgrywanie scenek rodzajowych.

Codziennik rosyjski wzbogaciłabym o krótkie informacje na temat słynnych Rosjan (np. przedstawicieli świata sportu, filmu, sztuki, mody, polityki). Więcej uwagi poświęciłabym także zjawiskom fonetycznym: akcentowi, intonacji, wymowie spółgłosek i samogłosek. Sądzę, że autorki książki powinny poszerzyć informacje na temat geografii Rosji: stref klimatycznych, przyrodniczych, czasowych czy Syberii. Według mnie brakuje również wiadomości o stereotypach na temat Rosjan. Aby skuteczniej zmotywować młodzież do nauki języka rosyjskiego, zamieściłabym przykładowe aplikacje na telefon, większą ilość adresów internetowych odsyłających do tradycji Rosji, świata filmu rosyjskiego, ćwiczeń utrwalających struktury gramatyczne.

Reasumując, należy podkreślić, że Codziennik jest pozycją godną uwagi. Polecam go szczególnie nauczycielom rusycystom jako pomoc dydaktyczną w praktycznej nauce języka rosyjskiego. Codziennik to według mnie książka powstała z myślą o pedagogach dążących do unikania monotonii, preferujących kreatywność i aktywizujące metody pracy, motywujących młodzież do samorozwoju. Uważam, że systematyczna praca z Codziennikiem rosyjskim przyczyni się do doskonalenia zarówno receptywnych, jak też produktywnych sprawności językowych: czytania, słuchania, mówienia i pisania.

Dr Katarzyna Czubała-Vyborov nauczyciel języka rosyjskiego i niemieckiego w Zespole Szkót Ekonomicznych i Mundurowych w Chetmie 